\title{
Recidív akut myocardialis infarctus pitvarfibrilláció miatt
}

\author{
Tomcsányi János dr. - Takó Katalin dr. - Sármán Balázs dr. \\ Budai Irgalmasrendi Kórház, Kardiológia, Budapest
}

\begin{abstract}
A pitvarfibrilláció ritka szövődménye a myocardialis infarctust okozó coronariaembolisatio. A szerzők egy 55 éves férfi kórtörténetét mutatják be, akinél egy évvel korábban paroxysmalis pitvarfibrilláció kíséretében coronariaembolisatiónak tartott akut myocardialis infarctus zajlott le. Egy évvel később ismételten mellkasi fájdalom, új keletü STeleváció és pitvarfibrilláció miatt került akut felvételre. Az első esetben a bal elülső leszálló coronariában, jelen esetben a circumflexa coronaria ágban láttak embolisatiónak megfelelő elzáródást. A transoesophagealis echokardiográfia fülcsethrombust igazolt. A pitvarfibrilláció jelen esetben is spontán megszúnt. A szerzők tudomása szerint ez az első eset, amikor pitvarfibrilláció kapcsán recidív akut myocardialis infarctus kerül leírásra. Orv. Hetil., 2016, 157(5), 191-193.
\end{abstract}

Kulcsszavak: pitvarfibrilláció, akut myocardialis infarctus, coronariaembolisatio, thromboembolia

\section{Recurrent acute myocardial infarction as a thromboembolic complication of atrial fibrillation}

\begin{abstract}
Coronary thromboembolism with subsequent myocardial infarction is a rare complication of atrial fibrillation. The authors present the history of a 55-year-old male with a history of acute myocardial infarction caused by thromboembolism in the distal part of left anterior descending coronary artery and paroxysmal atrial fibrillation, who presented one year later with new chest pain, ST-segment elevation and atrial fibrillation. Coronarography confirmed the presence of thrombus in the circumflex coronary artery. Transesophageal echocardiogram showed left atrial appendage thrombus. To the knowledge of the authors this is the first report of recurrent myocardial infarction caused by atrial fibrillation.
\end{abstract}

Keywords: atrial fibrillation, acute myocardial infarction, coronary artery embolism, thromboembolism

Tomcsányi, J., Takó, K., Sármán, B. [Recurrent acute myocardial infarction as a thromboembolic complication of atrial fibrillation]. Orv. Hetil., 2016, 157(5), 191-193.

(Beérkezett: 2015. november 2.; elfogadva: 2015. december 3.)

\section{Rövidítések}

NCVC = National Cerebral and Cardiovascular Center; TAGG = thrombocytaaggregáció-gátló; TEE = transoesophagealis echokardiográfia (nyelőcsövön keresztül végzett szív-ultrahangvizsgálat)

A pitvarfibrilláció egyik lehetséges szövődménye a thromboemboliás esemény, ennek a száma az életkor előrehaladtával egyre inkább növekszik [1]. A thromboemboliás kockázat becslésére korábban a $\mathrm{CHADS}_{2}$ és újabban a $\mathrm{CHA}_{2} \mathrm{DS}_{2}$-VASc score-ok szerepelnek. Ezek elsősorban a stroke rizikójára vonatkoznak [2]. A pitvarfibrilláció okozta coronariaembolisatióról leginkább kórbonctani vizsgálatok állnak rendelkezésre, illetve egy-egy esetriport [3-8]. Esetünket azért tartjuk bemutatásra érdemesnek, mert a recidív coronariaembolisatio okozta myocardialis infarctus felhívja a figyelmet az emboliaforrás keresésének fontosságára. Pitvarfibrillációban gyakran alacsony $\mathrm{CHADS}_{2}$ mellett jelentkezik a coronariaembolisatio, és ilyenkor mindenképpen antikoagulálás szükséges, mert ezzel kivédhetó az olyan eset, amikor a beteg ismételt akut myocardialis infarctust szenved el. 


\section{Esetismertetés}

A hypertoniás, dohányzó 55 éves férfi beteget 5 órája tartó mellkasi fájdalom, ST-eleváció és a tüneteket kísérő pitvarfibrilláció miatt referálták. Anamnézisében egy évvel korábban ST-eleváció miatt történt koronarográfia, ahol érfal-egyenetlenségen kívül a bal elülső coronaria distalis szakaszán találtak elzáródást, amit embolisatió-

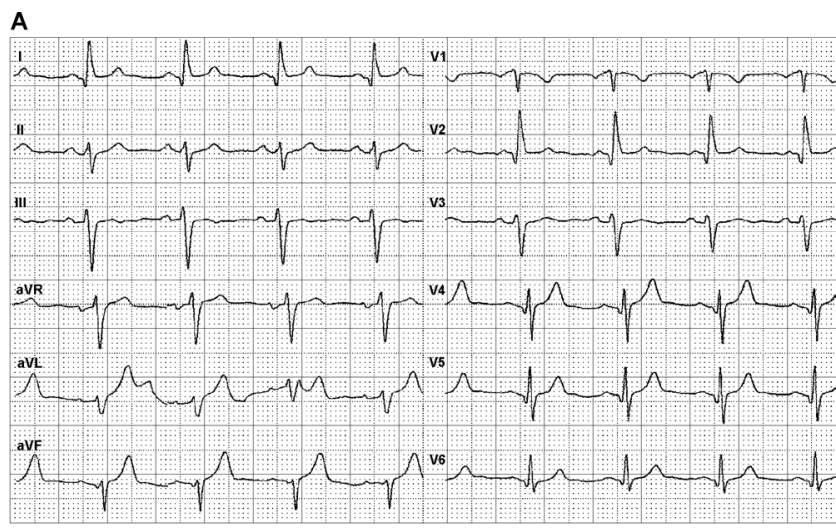

B
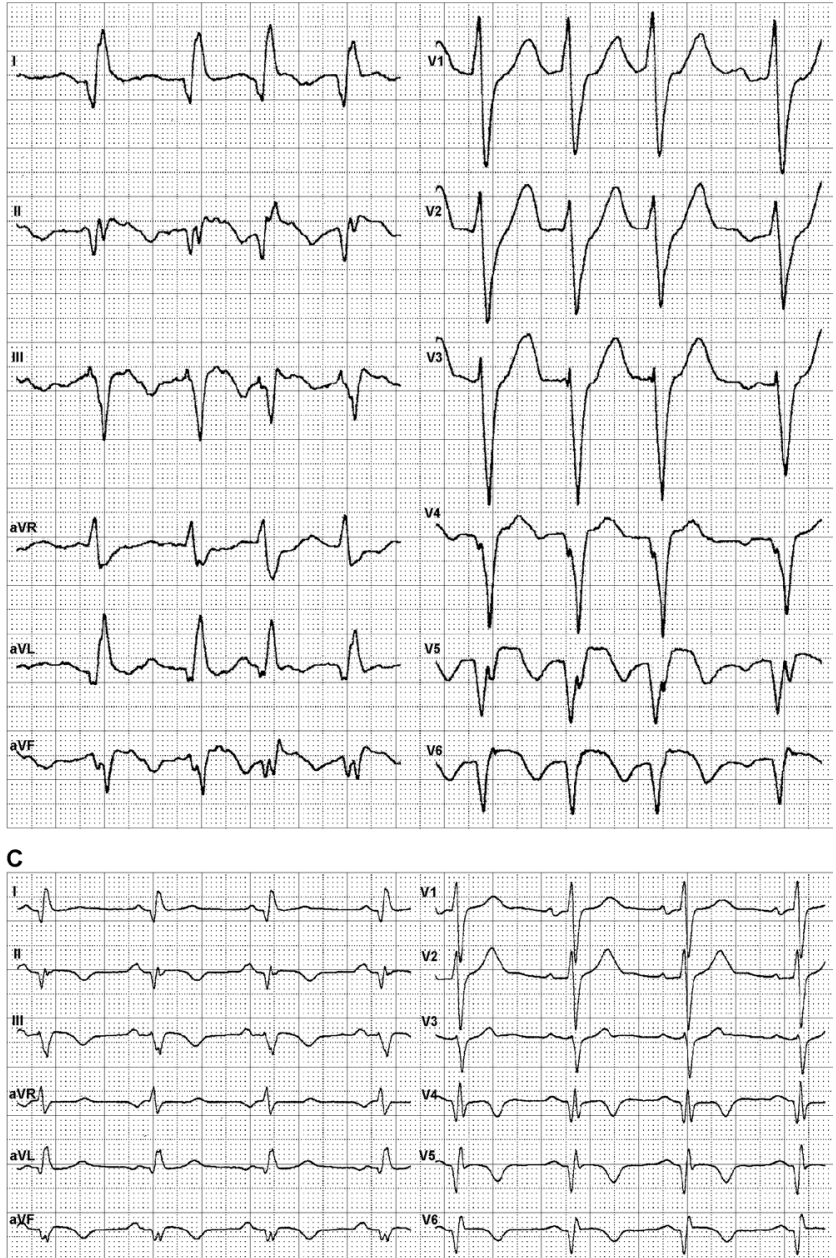

1. ábra

A) Recidív infarktus előtt, sinusrhythmusban. Régi infarktus Q hullámaival. B) Akut infarktusban a felvételi EKG. Pitvarfibrillá ció már inferior és V4-6 elvezetésekben látható Q-hullámmal, ST-elevációval. C) Hazabocsátásakor sinusrhythmus és új keletú Q-hullámokkal az inferior és a V4-6 elvezetésekben nak tartottak. A kíséró paroxysmalis pitvarfibrillációt amiodaronnal szüntették meg. Mivel ritmuszavara később nem jelentkezett, megelégedtek a kettős thrombocytaaggregáció-gátlással az alacsony $\mathrm{CHADS}_{2}$ score-ú betegnél. A kreatinkináz MB-frakció maximális értéke $92 \mathrm{U} / \mathrm{l}$ volt, a troponin $\mathrm{T}$ pedig $2,1 \mathrm{ng} / \mathrm{ml}$.

Jelen felvételét megelőzően egy hónappal készült EKG sinusrhythmus mellett a korábbi infarktus Q-hullámait mutatta az I-aVL elvezetésekben (1. A ábra). Gyógyszerei a kettős thrombocytaaggregáció-gátló (TAGG) mellett $40 \mathrm{mg}$ atorvastatin, $10 \mathrm{mg}$ ramipril és $25 \mathrm{mg}$ metoprolol voltak.

Felvételekor a mellkasi fájdalom mellett kiterjedt új keletû́ Q-hullámok voltak láthatók az inferior és V4-6 elvezetésekben, amit ST-eleváció is kísért (1. B ábra). A koronarográfia a circumflexa obtusa marginális ágának occlusióját mutatta (2. ábra). Mivel többször kanyar, illetve spasmus komprimálta a katétert, thrombusextractio nem volt kivitelezhető. Minitrack ballonnal történt tágítás, aminek hatására a kiáramlás némileg javult, de a distalis embolisatio megmaradt. Ezért a beteg 36 órás GP $2 \mathrm{~b} / 3 \mathrm{a}$ intergrillin infúziós kezelésben részesült. A maximális kreatinkináz-kiáramlás $574 \mathrm{U} / 1$ (normális: $\leq 170$ $\mathrm{U} / \mathrm{L}$ ), a troponin-T $3,75 \mathrm{ng} / \mathrm{ml}$ (normális: $\leq 0,005 \mathrm{ng} /$ $\mathrm{ml}$ ) volt. Pajzsmirigyfunkció rendben volt. Statinterápia mellett az LDL-koleszterin 1,9 mmol/L volt. Az emboliaforrást keresve transoesophagealis vizsgálatot végeztünk, ami $1,2 \mathrm{~cm}$-es fülcsethrombust igazolt (3. ábra).

A beteg a sinusrhytmus spontán helyreállását nem érezte meg a 3. napon. A kórházból sinusrhythmussal távozott (1. C ábra), de a kettős TAGG-kezelést orális antikoagulánssal egészítettük ki.

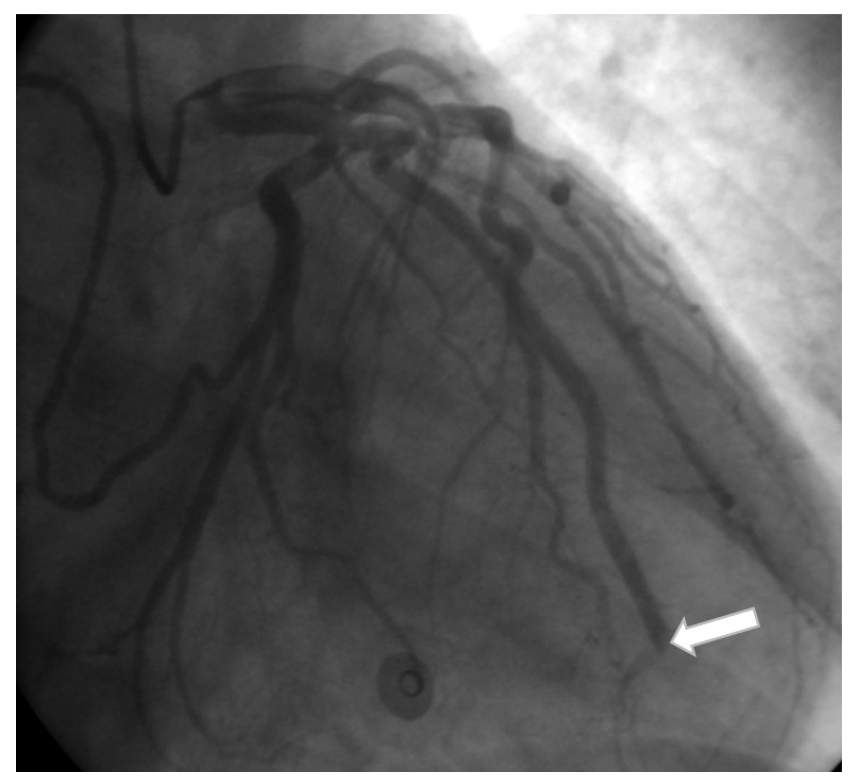

2. ábra

Koronarográfia során a bal circumflexa coronaria OM-ágán a nyíllal jelölt helyen occlusio TIMI 0 áramlással 


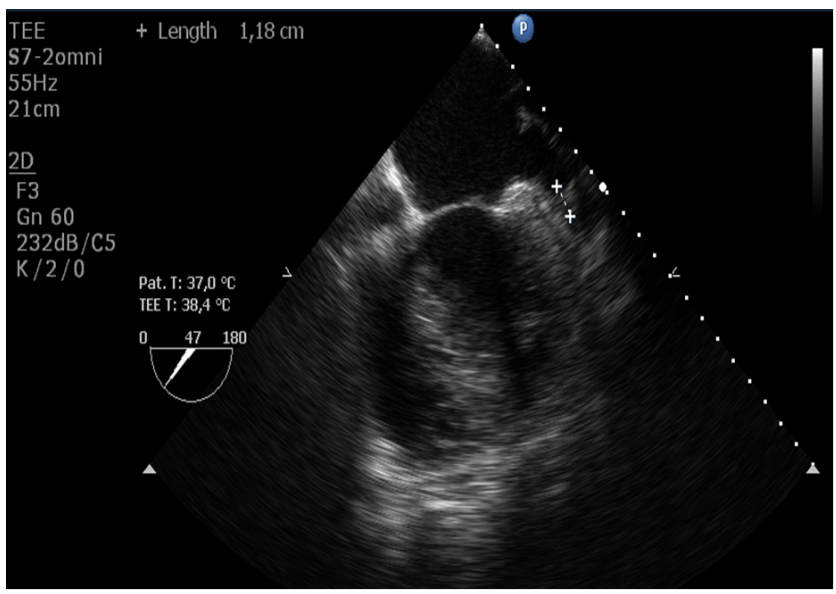

3. ábra

Transoesophagealis echokardiográfia végzésekor a fülcsében egy $12 \mathrm{~mm}$-es, thrombusnak imponáló echodenz képlet látható

\section{Megbeszélés}

A coronariaembolisatio klinikai diagnosztikájára az NCVC (National Cerebral and Cardiovascular Center) három major és három minor feltételből álló diagnosztikus kritériumrendszert állított fel [9].

Major kritériumok: 1. angiológiai igazolása az atherosclerosis nélküli coronariaembolisatiónak; 2 . több helyen jelentkező coronariaembolisatio; 3. kísérő szisztémás embolisatio.

Minor kritériumok: 1. culprit laesiót kivéve a többi helyen $25 \%$ alatti szúkületek mértéke; 2 . egyértelmű emboliaforrás az echo-, transoesophagealis szívultrahang-, CT- vagy MR-vizsgálatok alapján; 3. emboliás kockázati faktorok megléte (pitvarfibrilláció, cardiomyopathia, reumás billentyúbetegség, múbillentyü, nyitott foramen ovale, pitvari septumdefektus, szívsebészeti beavatkozás korábban, infektív endocarditis, hypercoagulabilitás.

Definitín a coronariaembolisatio diagnózisa: kettő vagy több major kritérium vagy egy major és kettő/több minor kritérium vagy három minor kritérium esetén.

Valószinü a coronariaembolisatio diagnózisa: egy major és egy minor kritérium vagy két minor kritérium esetén.

Esetünkben egy major kritérium és két minor kritérium alapján definitívnek mondható a diagnózis. Esetünk legfóbb tanulsága, hogy coronariaembolisatio esetén agresszíven keresni kell az emboliaforrást és az alacsony $\mathrm{CHADS}_{2}$ score-ú paroxysmalis pitvarfibrilláció is okozhat coronariaembolisatiót, sőt az esetek jelentős részében ez okozza. Ezért ilyen esetekben az oralis antikoaguláns beállítása feltétlen indokolt a recidív embolisatiók elkerülésére, aminek az előfordulása $8,7 \%$ az összes coronariaemboliák tekintetében [9]. Fiatal korban jelentkező szívinfarktus oka is lehet a coronariaembolisatio [10], ezért, ha a beteg kivizsgálására lehetőség van, erre is gondolni kell, még akkor is, ha az infarktus észlelésekor a beteg sinusrhythmusban van.

Anyagi támogatás: A közlemény megírása anyagi támogatásban nem részesült.

Szerzői munkamegosztás: T. J.: A cikk megírása, a TEEvizsgálat végzése. T. K.: A beteg osztályos ellátása. S. B.: A szívkatéteres vizsgálat elvégzése. A cikk végleges változatát mindhárom szerző elolvasta és jóváhagyta.

Érdekeltségek: A szerzőknek nincsenek érdekeltségeik.

\section{Köszönetnyilvánítás}

A szerzők köszönik Tordas Györgynek az EKG-regisztrátumok elkészítésében nyújtott segítségét.

\section{Irodalom}

[1] Chugh, S. S., Blackshear, J. L., Shen, W. K., et al.: Epidemiology and natural history of atrial fibrillation: clinical implications. J. Am. Coll. Cardiol., 2001, 37(2), 371-378.

[2] Lip, G. ., Nieuwlaat, R., Pisters, R., et al.: Refining clinical risk stratification for predicting stroke and thromboembolism in atrial fibrillation using a novel risk factor-based-approach: the Euro Heart Survey on atrial fibrillation. Chest, 2010, 137(2), 263-272.

[3] Prizel, K. R., Hutchins, G. M., Bulkley, B. H.: Coronary artery embolism and myocardial infarction. Ann. Intern. Med., 1978, $88(2), 155-161$.

[4] Garg, R. K., Jolly, N.: Acute myocardial infarction secondary to thromboembolism in a patient with atrial fibrillation. Int. J. Cardiol., 2007, 123(1), e18-e20.

[5] Van de Walle, S., Dujardin, K.: A case of coronary embolism in a patient with paroxysmal atrial fibrillation receiving tamoxifen. Int. J. Cardiol., 2007, 123(1), 66-68.

[6] Acikel, S., Dogan, M., Aksoy, M. M., et al.: Coronary embolism causing non-ST elevation myocardial infarction in a patient with paroxysmal atrial fibrillation: treatment with thrombus aspiration catheter. Int. J. Cardiol., 2011, 149(1), e33-e35.

[7] Camaro, C., Aengevaeren, W. R.: Acute myocardial infarction due to coronary artery embolism in a patient with atrial fibrillation. Neth. Heart J., 2009, 17(7-8), 297-299.

[8] Ilia, R., Weinstein, J. M., Wolak, A., et al.: Coronary thrombus in ST elevation myocardial infarction and atrial fibrillation. J. Thromb. Thrombolysis, 2013, 35(1), 119-122.

[9] Shibata, T., Kawakami, S., Noguchi, T., et al.: Prevalence, clinical features, and prognosis of acute myocardial infarction attributable to coronary artery embolism. Circulation, 2015, 132(4), 241-250.

[10] Nagy, G. Z., Gerges, G., Csapó, K.: Rare case of myocardial infarct in a young adult. [Ritka etiológiájú fiatalkori szívinfarktus.] Orv. Hetil., 2015, 156(25), 1020-1025. [Hungarian]

(Tomcsányi János dr., Budapest, Árpád fejedelem u. 7., 1023 e-mail: tomcsanyij@gmail.com) 